\title{
JNPH
}

Volume 6 No. 1 (April 2018)

(C) The Author(s) 2018

\section{FAKTOR-FAKTOR YANG MEMPENGARUHI PENURUNAN NYERI POST OPERASI SECTIO CAESAREA DI RS. RAFLESSIA BENGKULU}

\author{
FACTORS THAT AFFECT DECREASE OF POST OPERATION SECTIO CAESAREA \\ IN RS. RAFLESSIA BENGKULU
}

\author{
DES METASARI DAN BERLIAN KANDO SIANIPAR \\ DOSEN FIKES UNIVERSITAS DEHASEN BENGKULU PROGRAM \\ STUDI DIII KEPERAWATAN \\ Email: desmetaheri@gmail.com, berliankando@gmail.com
}

\begin{abstract}
ABSTRAK
Tindakan Sectio cassarea (SC) merupakan salah satu alternatif bagi seorang wanita dalam memilih proses persalinan di samping adanya indikasi medis dan indikasi non medis, tindakan SC akan memutuskan kontinuitas atau persambungan jaringan karena insisi yang akan mengeluarakan reseptor nyeri. Mobilisasi dini merupakan faktor yang dapat mengurangi nyeri pasca bedah sedangkan teknik relaksasi adalah metode pengalihan nyeri non farmakologi yang dapat mengurangi komponen sensori nyeri. Tujuan penelitian ini adalah diketahuinya faktorfaktor yang dapat mempengaruhi penurunan intensitas nyeri postoperasi SC yaitu teknik mobilisasi dan teknik relaksasi, penelitian ini dilaksankan di RS Raflessia Bengkulu pada Bulan Agustus s/d September 2017 dengan jumlah sampel 40 orang ibu postpartum dengan teknik pengambilan sampel accidental sampling. Metode penilitian ini menggunakan eksperimen semu (Quasy experiment), dengan pendekatan One Group Pre-Post Test yang bertujuan untuk melihat pengaruh mobilisasi dini terhadap intensitas nyeri pada pasien post op sectio cessarea. Hasil penelitian terdapat rata-rata penurunan tingkat nyeri setelah dilakukan mobilisasi dini sebanyak 2,2, terjadi penurunan tingkat nyeri setelah dilakukan teknik relaksasi sebesar 2,1 dan terdapat pengaruh mobilisasi dini terhadap penurunan intensitas nyeri dengan nilai $p(0,000)$. Disarankan kepada pihak rumah sakit untuk dapat memaksimalkan pelaksanaan mobilisasi dini 6 jam postoperasi pada ibu postpartum dengan SC dan melakukan teknik mobilisasi dini terhadap ibu postpartum dengan SC secara terut dan benar untuk mengurangi rasa nyeri akibat insisi luka operasi
\end{abstract}

Kata kunci: Mobilisasi dini, teknik relaksasi, sectio caesarea

\begin{abstract}
The action of Sectio cassarea (SC) is one of the alternatives for a woman in choosing the delivery process in addition to medical indications and non-medical indications, SC action will discontinue continuity or tissue linkage because of the incision that will release pain receptors. Early mobilization is a factor that can reduce post-surgical pain while relaxation technique is a non-pharmacological pain transfer method that can reduce the pain sensory component. The purpose of this research is to know the factors that can influence the decrease in intensity of postoperative SC pain which is the technique of mobilization and relaxation technique, this research is done in RS Raflessia Bengkulu in August until September 2017 with sample 40
\end{abstract}


peoples postpartum mother with accidental sampling technique sampling. This method of research using quasy experiment, with approach of One Group Pre-Post Test which aims to see the effect of early mobilization to the intensity of pain in patients post-sectio cessarea. The results of the study showed an average decrease in pain level after early mobilization of 2.2 , a decrease of pain level after relaxation technique of 2.1 and there was an effect of early mobilization on the decrease of pain intensity with $p$ value $(0.000)$. It is suggested to the hospital to maximize the implementation of early mobilization of 6 hours postoperative on postpartum mother with SC and perform early mobilization technique to postpartum mother with SC in a correct and correct way to reduce the pain due to surgical incision wound

Keywords: Early mobilization, relaxation technique, sectio caesarea

\section{PENDAHULUAN}

Tindakan Sectio cassarea (SC) merupakan salah satu alternatif bagi seorang wanita dalam memilih proses persalinan di samping adanya indikasi medis dan indikasi non medis, tindakan SC akan memutuskan kontinuitas atau persambungan jaringan karena insisi yang akan mengeluarakan reseptor nyeri sehingga pasien akan merasakan nyeri terutama setelah efek anastesi habis.

Rasa nyeri dapat menimbulkan stressor dimana individu berespon secara biologis dan hal ini dapat menimbulkan respon perilaku fisik dan psikologis. Mobilisasi dini adalah upaya untuk memandirikan pasien secara bertahap mengingat besarnya tanggung jawab yang harus dilakukan oleh ibu untuk pemulihannya dan merawat bayinya, namun banyak ibu takut melakukan pergerakan karena takut merasa nyeri padahal pergerakan itu dapat mengurangi nyeri selain itu mobilisasi dini dapat melatih kemandirian ibu, teknik non farmakologis lainnya yang bias dilakukan oleh ibu postpartum yaitu melakukan teknik relaksasi secara teratur dan benar, teknik relaksasi akan mengurangi intensitas nyeri ibu post SC dan membantu relaksasi otot serta membantu pernafasan menjadi lebih baik

Menurut Word Health Organitation (WHO) memperkirakan pada tahun 2008dilaporkan bahwa wanita melahirkan dengan SC sebanyak 35\% dari seluruh persalinan, sedangkan di Indonesia berdasarkan hasil Riskesdas 2010 menyatakan terdapat $15,3 \%$ persalinan dilakukan melalui operasi. Provinsi tertinggi dengan persalinan melalui SC adalah DKI Jakarta (27,2\%), Kepulauan Riau (24,7\%), dan Sumatera Barat (23,1\%) (Depkes RI, 2011).

Berdasarkan data Rekam Medik dari rumah sakit Raflessia Bengkulu pada tahun 2014 jumlah ibu yang melakukan SC berjumlah 905 orang, tahun 2015 jumlah ibu yang melakukan SC meningkat menjadi 1086, tahun 2015 berjumlah 1010 dan tahun 2016 priode Januari s/d Desember berjumlah 172 orang ibu yang melakukan SC. Hal ini menunjukkan bahwa Tindakan Sectio caesarea dari tahun ketahun mengalami peningkatan.

Peningkatan ini diduga karena teknik dan fasilitas bertambah baik, operasi berlangsung lebih aseptik, teknik anestesi bertambah baik, kenyamanan pasectio caesareaa operasi semakin tinggi, dan lama rawat bertambah pendek serta dapat memilih tanggal kelahiran sesuai keinginan (Roeshadi,2006). Namun demikian operasi Caesarea bukan berarti bebas dari resiko atau masalah.

Penelitian oleh Hillan mengenai rasa nyeri post Sectio diketahui bahwa pada hari ke 1-2 klien masih mengalami nyeri pada luka, dan bahkan hampir pada separuh wanita berlangsung sampai mereka pulang ke rumah, dan bahkan sekitar $32 \%$ pasien yang dilakukan operasi sesar masih mengalami nyeri pada luka, dan tidak jarang nyeri pada luka setelah pulang bertambah berat sehingga membutuhkan obat analgesik.

Terdapat beberapa hal yang bisa dilakukan oleh ibu postpartum dengan SC 
untuk mengurangi nyeri yang dialaminya, selain tindakan pemberian anlgetik diantaranya mobilisasi dini merupakan faktor yang menonjol dalam mempercepat pemulihan pascabedah dan dapat mencegah komplikasi pascabedah, dengan mobilisasi dini diharapkan ibu nifas dapat menjadi lebih sehat dan lebih kuat, selain itu juga dapat melancarkan pengeluaran lochea, membantu proses penyembuhan luka akibat proses persalinan, mempercepat involusio uteri, melancarkan fungsi alat gastro intestinal dan alat perkemihan serta meningkatkan kelancaran peredaran darah, sehingga mempercepat pengeluaran Air Susu Ibu (ASI) dan pengeluaran sisa metabolisme (Manuaba, 2008).

Berdasarkan hasil penelitian yang dilakukan oleh Handayani tahun 2015, di RSUD Moewardi, hasilnya menunjukkan ada pengaruh mobilisasi dini terhadap skala nyeri dengan nilai $\mathrm{Z}$ score $=-6,835$ dengan nilai Pvalue $=0,000$.

Menurut Steer tahun 2004 menyatakan bahwa relaksasi adalah metode pengalihan nyeri non farmakologi yang sering digunakan di Inggris. Steer dalam studinya melaporkan bahwa sebanyak 34 wanita menggunakan relaksasi, dengan melakukan induksi relaksasi selama 15 menit secara signifikan dapat mengurangi komponen sensori nyeri. Pillips menambahkan bahwa komponen emosional nyeri juga berkurang sehinggaefek kecemasan yang memperburuk juga berkurang akibat dampak dari relaksasi (Mander, 2004).

Relaksasi dapat digunakan dalam episode nyeri akut maupun kronik untuk menurunkan nyeri. Biasanya dibutuhkan 5-10 sesi pelatihan sebelum klien dapatMeminimalkan nyeri secara efektif. Pasien yang sudah mengetahui tentang teknik relaksasi mungkin hanya perlu diingatkan kembali untuk menggunakan teknik tersebut untuk mengurangi atau mencegah meningkatnya nyeri. Tujuan pokok relaksasi adalah untuk membantu orang menjadi rileks, dan dengan demikian memperbaiki berbagai aspek kesehatan fisik.Disamping itu ada pula beberapa manfaat lain, yaitu menimbulkan ketentraman batin, berkurangnya rasacemas, detak jantung lebih rendah, mengurangi tekanan darah, ketahanan yang lebih besar terhadap penyakit, kesehatan mental. menjadi lebih baik, dan daya ingat lebih baik.

Berdasarkan uraian dalam latar belakang di atas, didapatkan masalah penelitian banyak ibu yang takut melakukan mobilisasi dan belum sepenuhnya menjalankan teknik relaksasi yang terstruktur dan teratur serta berkesinmabungan sehingga masih merasakan nyeri postoperasi yang membuat ibu postpartum tidak bias menyusui bayinya lebih dini dan ketergantungan dalam berkativitas dan memenuhi ADL, sehingga dapat dirumuskan pertanyaan penelitian "Apakah faktor faktor yang mempengaruhi nyeri post operasi section caesarea pada ibu postpartum di RS.Raflessia Bengkulu? dini terhadap intensitas nyeri post operasi SC di rumah Bhayangkara Polda Bengkulu Bengkulu?".

Tujuan Umum penelitian ini diketahuinya faktor-faktor yang mempengaruhi penurunan nyeri postoperasi sectio caesarea pada ibu postpartum di RS.Raflessia Bengkulu tahun 2017, sedangkan tujuan khusus penelitian ini diketahuinya gambaran intensitas nyeri postoperasi sectio caesarea pada ibu postpartum sebelum dan setelah dilakukan teknik mobilisasi dini, diketahuinya gambaran intensitas nyeri postoperasi pada ibu postpartum sebelum dan setelah dilakukan teknik relaksasi, diketahuinya pengaruh teknik mobilisasi dini terhadap penurunan intensitas nyeri postoperasi SC pada ibu postpartum SC, diketahuinya pengaruh teknik relaksasi terhadap penurunan intensitas nyeri pada ibu postpartum SC di Rumah sakit Raflessia Bengkulu tahun 2017.

Manfaat praktis penelitian ini diharapkan dapat memberi masukan kepada pihak rumah sakit dalam memberikan pelayanan kesehatan terutama mengajarkan teknik mobilisasi dini dan teknik relaksasi pada ibu postpartum dengan SC sehingga dapat mengurangi rasa nyeri yang ibu alami dan akan memaksimalkan kegiatan ibu dalam merawat 
bayinya dan laktasi.

\section{METODE}

Penelitian ini Jenis penelitian yang digunakan adalah desain penelitian eksperimen semu (Quasy experiment).Karena peneliti tidak mengontrol semua variabel yang relevan, dengan pendekatan One Group Pre-Post Test yang bertujuan untuk melihat pengaruh mobilisasi dini terhadap intensitas nyeri pada pasien post op sectio cessarea. Bentuk rancangan penelitian sebagai berikut:

Q1X1 Keterangan:

Q1:Skala nyeri sebelum pemberian mobilisasi dini dan sebelum pemberian teknik relaksasi $\mathrm{X} 1$ :Skala nyeri sesudah pemberian mobilisasi dini dan sebelum pemberian teknik relaksasi.

Sampel dalam penelitian ini adalah ibu postpartum dengan SC yang dirawat di RS.Raflessia Bengkulu yang berjumlah 40 orang ibu pada tahun 2016 yang diambil dengan teknik accidental sampling.

Penelitian ini dilakukan rumah sakit Raflessia Bengkulu, dari bulan Agustus s/d September 2017. dengan tahapan penelitian sebagai berikut: pengumpulan data setelah mendapatkan izin dari kepala RS Raflessia Bengkulu, peneliti mengajukan surat permohonan kepada responden, pengambilan data pada penelitian ini menggunakan data primer dengan mengukur skala nyeri menggunakan Numeric Rating Scale (NRS). Pengukuran nyeri dilakukan pada menit ke 60 dengan tiga kali intervensi mobilisasi dini masing-masing15 menit untuk setiap kali intervensi, mobilisasi dini diukur dengan lembar cheklist mobilisasi dini dan diamati oleh peneliti langsung saat pasien melakukan mobilisasi dini, sedangkan untuk variabel teknik relaksasi digunakan oleh peneliti menggunakan lembar checklist teknik relaksasi dan peneliti langsung mengajarkan dan melihat responden melakukan teknik relaksasi, latihan relaksasi oleh responden dengan masing-masing waktu latihan 15 menit (3x latihan dimulai dari persiapan s/d latihan), sehingga total teknik relaksasi yang dilakukan oleh masing-masing responden sebanyak 9 kali.

Setelah data terkumpul data kemudian diolah dengan sistem komputer menggunkan SPSS 17. Untuk memudahkan pengolahan data, data yang terkumpul berdasarkan pedoman penskoran menurut variabel penelitian kemudian data dijumlahkan berdasarkan hasil kuesioner pada setiap alternatif jawaban kemudian melalui beberapa tahap pengolahan data: Mengedit (Editing), pengkodean (Coding), entry data, pembersihan data (Cleaning), analisis Data yang terdiri dari analisa univariat dan analisa bivariat.

\section{HASIL}

Data yang diperoleh kemudian diolah menggunakan program komputer dengan SPSS 17, dari hasil pengolahan data maka dilakukan analisis Univariat untuk mengetahui gambaran distribusi frekuensi masing - masing variabel penelitian dan analisis Bivariat untuk mengetahui hubungan antar variabel yaitu variabel independen (teknik mobilisasi dini dan teknik relaksasi) dengan variabel dependen (penurunan intensitas nyeri post operasi SC), adapun hasil penelitiannya adalah: Analisis ini dilakukan untuk melihat distribusi frekuensi penurunan intensitas nyeri post operasi SC. Adapun hasil analisisnya sebagai berikut:

Tabel 1. Gambaran Distribusi Frekuensi Responden Berdasarkan Intensitas Nyeri sebelum dan setelah dilakukan teknik mobilisasi dini pada ibu postpartum di RS.Raflessia Bengkulu Tahun 2017

\begin{tabular}{ccccc}
\hline \multirow{2}{*}{ No } & $\begin{array}{c}\text { Mobilisasi } \\
\text { Dini }\end{array}$ & $\begin{array}{c}\text { Tingkat } \\
\text { Nyeri }\end{array}$ & Frekuensi $\begin{array}{c}\text { Persentase } \\
\text { (\%) }\end{array}$ \\
\hline 1 & Sebelum & 1 & 5 & 12,5 \\
\cline { 2 - 5 } & Setelah & 1 & 1 & 2,5 \\
\hline 2 & Sebelum & 2 & 14 & 35,0 \\
\cline { 2 - 5 } & Setelah & 2 & 4 & 10,0 \\
\hline 3 & Sebelum & 3 & 14 & 35,0 \\
\hline
\end{tabular}




\begin{tabular}{ccccc}
\hline & Setelah & 3 & 18 & 45,0 \\
\hline \multirow{2}{*}{4} & Sebelum & 4 & 7 & 17,5 \\
\cline { 2 - 5 } & Setelah & 4 & 14 & 35,0 \\
\hline 5 & Sebelum & 5 & 0 & 0 \\
\cline { 2 - 5 } & Setelah & 5 & 3 & 7,5 \\
\hline \multirow{3}{*}{$\begin{array}{c}\text { Total } \\
\text { sebelum OP }\end{array}$} & & 40 & 100 \\
\cline { 2 - 5 } $\begin{array}{c}\text { Total setelah } \\
\text { OP }\end{array}$ & 40 & 100
\end{tabular}

Sumber : Data penelitian 2017

Berdasarkan Tabel 1, menunjukkan bahwa hampir sebagian responden mengalami tingkat nyeri 5 dan 6 berjumlah $14(35,0 \%)$ dan hampir sebagian responden mengalami tingkat nyeri 3 berjumlah $18(45,0 \%)$.

Tabel 2. Gambaran Distribusi Frekuensi Responden Berdasarkan Intensitas Nyeri sebelum dan setelah dilakukan teknik Relaksasi pada ibu postpartum di RS.Raflessia Bengkulu Tahun 2017

\begin{tabular}{ccccc}
\hline No & Relaksasi & $\begin{array}{c}\text { Tingkat } \\
\text { Nyeri }\end{array}$ & $\begin{array}{c}\text { Frekuensi } \\
\begin{array}{c}\text { Persentase } \\
(\%)\end{array}\end{array}$ \\
\hline 1 & Sebelum & 1 & 5 & 12,5 \\
\cline { 2 - 5 } & Setelah & 1 & 1 & 2,5 \\
\hline 2 & Sebelum & 2 & 14 & 35,0 \\
\cline { 2 - 5 } & Setelah & 2 & 4 & 10,0 \\
\hline 3 & Sebelum & 3 & 14 & 35,0 \\
\cline { 2 - 5 } & Setelah & 3 & 18 & 45,0 \\
\hline 4 & Sebelum & 4 & 7 & 17,5 \\
\cline { 2 - 5 } & Setelah & 4 & 15 & 37,5 \\
\hline 5 & Sebelum & 5 & 0 & 0 \\
\cline { 2 - 5 } & Setelah & 5 & 2 & 5,0 \\
\hline \multirow{4}{*}{$\begin{array}{c}\text { Total } \\
\text { sebelum OP }\end{array}$} & & 40 & 100 \\
\cline { 2 - 5 } & Total setelah & & \\
& OP & 40 & 100 \\
\hline
\end{tabular}

Sumber : Data penelitian 2017

Berdasarkan Tabel 2, menunjukkan bahwa hampir sebagian responden mengalami tingkat nyeri 5 dan 6 berjumlah $15(37,5 \%)$ dan hampir sebagian responden mengalami tingkat nyeri 3 berjumlah $18(45,0 \%)$

Tabel 3. Pengaruh Teknik Mobilisasi Dini Terhadap Penurunan Nyeri Post operasi Sectio Caesarea Pada Ibu Postpartum di
RS.Raflessia Bengkulu Tahun 2017

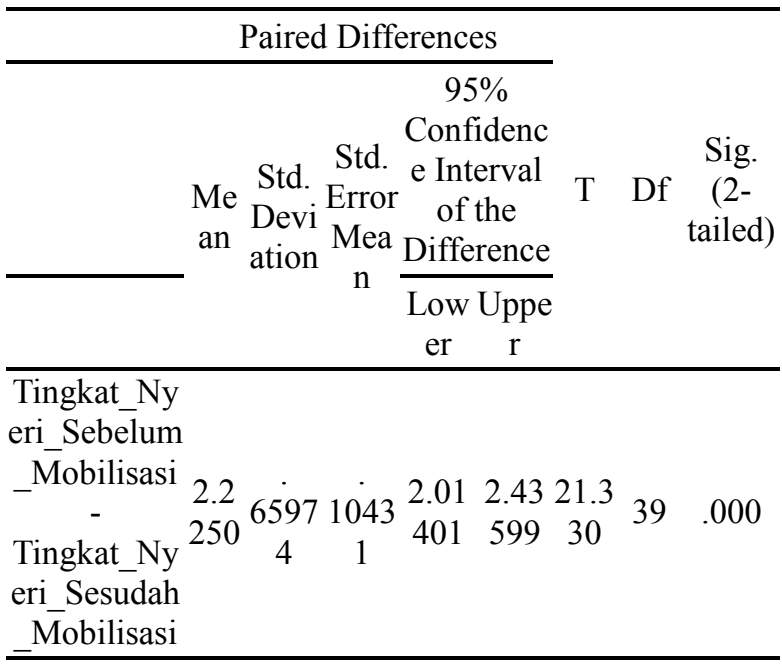

Sumber : Data penelitian 2017

Berdasarkan tabel 3 bahwa rata-rata penurunan tingkat nyeri adalah 2,2 dan terdapat pengaruh mobilisasi dini terhadap penurunan intensitas nyeri dimana nilai $p \leq$ 0,05 dan nilai $p(0,000)$.

Tabel 4. Pengaruh Teknik Relaksasi Terhadap Penurunan Nyeri Post operasi Sectio Caesarea Pada Ibu Postpartum di RS.Raflessia Bengkulu Tahun 2017

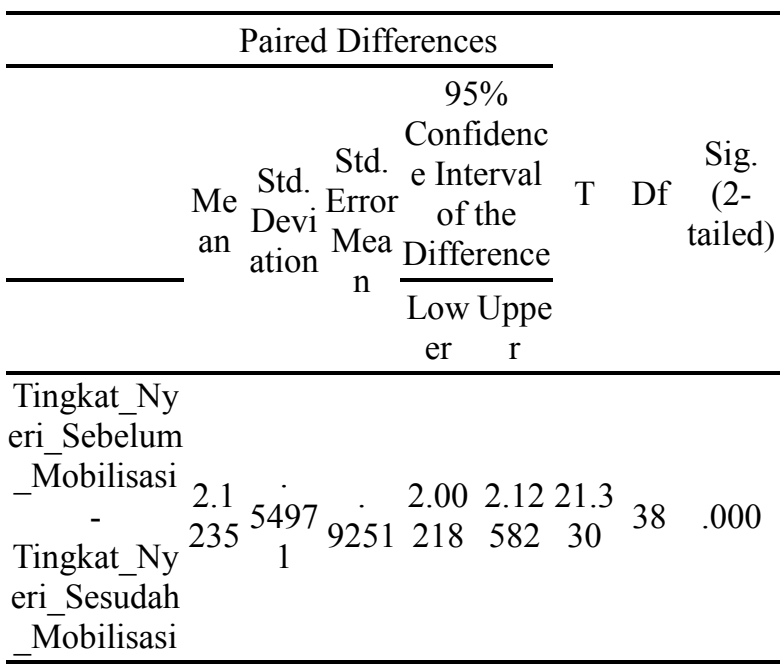

Sumber : Data penelitian 2017

Berdasarkan tabel 4 bahwa rata-rata penurunan tingkat nyeri adalah 2,1 dan terdapat pengaruh teknik relaksasi terhadap 
penurunan intensitas nyeri dengan nilai $p \leq$ 0,05 dan nilai $p(0,000)$.

\section{DISKUSI}

Hasil penelitian menunjukkan bahwa terdapat rata-rata penurunan tingkat nyeri setelah dilakukan mobilisasi dini sebanyak 2,2 terjadi penurunan tingkat nyeri setelah dilakukan teknik elaksasi sebesar 2,1dan adalah 2,1 dan terdapat pengaruh mobilisasi dini terhadap penurunan intensitas nyeri dimana nilai $p \leq 0,05$ dan nilai $p(0,000)$.

Hasil penelitian ini sejalan dengan penelitian Arum (2011) menunjukkan bahwa tingkat nyeri menurun dari nyeri sedang dan nyeri ringan, seiring dengan mobilisasi dini yang dilakukan sehingga mampu mencapai tingkat aktifitas normal seperti biasanya dan dapat memenuhi kebutuhan gerak harian. Mobilisasi dini adalah upaya untuk memandirikan pasien secara bertahap mengingat besarnya tanggung jawab yang harus dilakukan oleh ibu untuk pemulihannya dan merawat bayinya, namun banyak ibu takut melakukan pergerakan karena takut merasa nyeri padahal pergerakan itu dapat mengurangi nyeri selain itu mobilisasi dini dapat melatih kemandirian ibu.

Adanya perbedaan intensitas nyeri responden disebabkan oleh karena pemberian teknik relaksasi nafas dalam itu sendiri, jika teknik relaksasi nafas dalam dilakukan secara benar maka akan menimbulkan penurunan nyeri yang dirasakan sangat berkurang/optimal dan pasien sudah merasa nyaman disbanding sebelumnya, sebaliknya jika teknik relaksasi nafas dalam dilakukan dengan tidak benar, maka nyeri yang dirasakan sedikit berkurang namun masih terasa nyeri dan pasien merasa tidak nyaman dengan keadaannya. Hal ini dapat mempengaruhi intensitas nyeri, karena jika teknik relaksasi nafas dalam yang dilakukan secara berulang akan dapat menimbulkan rasa nyaman yang pada akhirnya akan meningkatkan toleransi persepsi dalam menurunkan rasa nyeri yang dialami. Jika seseorang mampumeningkatkan toleransinya terhadap nyeri maka seseorang akan mampu beradaptasi dengan nyeri, dan juga akan memiliki pertahanan diri yang baik pula (Lukman 2013).

\section{KESIMPULAN}

Hasil penelitian tentang faktor-faktor yang mempengaruhi penurunan nyeri post operasi SC pada ibu postpartum di RS.Raflessia Bengkulu tahun 2017, dapat ditarik kesimpulan sebagai berikut: hampir sebagian responden mengalami tingkat nyeri 5 dan 6 berjumlah $14(35,0 \%)$ dan hampir sebagian responden mengalami tingkat nyeri 3 berjumlah $18(45,0 \%)$, hampir sebagian responden mengalami tingkat nyeri 5 dan 6 berjumlah $15(37,5 \%)$ dan hampir sebagian responden mengalami tingkat nyeri 3 berjumlah $18(45,0 \%)$ dan terdapat rata-rata penurunan tingkat nyeri setelah dilakukan mobilisasi dini sebanyak 2,2, terjadi penurunan tingkat nyeri setelah dilakukan teknik relaksasi sebesar 2,1 dan terdapat pengaruh mobilisasi dini terhadap penurunan intensitas nyeri dimana nilai $p \leq 0,05$ dan nilai $p(0,000)$.

\section{SARAN}

Saran dalam penelitian ini dapat disarankan kepada pihak rumah sakit untuk dapat memaksimalkan pelaksanaan mobilisasi dini 6 jam postoperasi pada ibu postpartum dengan SC dan melakukan teknik mobilisasi dini terhadap ibu postpartum dengan SC secara terut dan benar untuk mengurangi rasa nyeri akibat insisi luka operasi, rasa nyeri yang berkurang akan memaksimalkan kegiatan ibu untuk merawat bayinya dan memberikan laktasi (Insiasi menyusui dini dan ASI ekslusif)

\section{DAFTAR PUSTAKA}

Arum R (2011), Hubungan Mobilisasi Dini
dengan Intensitas ibu post sectio
caesarea di RSD Haryoto Lumajang,
Jurnal Kesehatan, Universitas 
Brawijaya Malang.

Astutik, P (2014). Mobilisasi Terhadap Penurunan Tingkat Nyeri Ibu Postoperasi Sectio Caesarea di Care Unit Ruang Post Anesthesia RSUD dr. Harjono Ponogroho. Jurnal Kesehatan Stikes Satriya Bhakti Nganjuk, Vol. 1, No. 1, Juni 2014

Carpenito, L, J. (2009). Diagnosis Keperawatan, Aplikasi Pada Praktek Klinis : Edisi 9. Jakarta : EGC

Corwin, E.J (2006). Patofisiologi. Jakarta : EGC

Dewi, Nia Risa, Siregar, Maimah Rafni. 2008. Faktor-Faktor yang Berhubungan dengan Pelaksanaan Ambulasi Dini Pada Ibu Postpartum dengan Sectio Caesarea Di Ruang Rawat Gabung IRNA Kebidanan dan Penyakit kandungan RSUP Dr. Moh. Hoesin Palembang Tahun 2007. Jurnal Generic. ISSN 1907-4093, diakses 9 April 2016 dari http://eprints.unsri.ac.id

Cahyono, Aris dwi (2014). Pengaruh Relaksasi Progresif Terhadap Penurunan Nyeri pada Pasien Post Operasi Sectio Caessarea pada Hari Ke 1-2 di RS.Kediri. JURNAL AKP VOL 5 EDISI 1 JULI S/D 31 DESEMBER 2014.

Grace C. (2012). Pengetahuan, Sikap dan Pelaksanaan Mobilisasi Dini Ibu Pasca Salin dengan Seksio Sesaria. Jurnal Kesehatan. Fakultas Keperawatan Universitas Sumatera Utara

Kasdu, D (2005). Operasi Caesar Masalah dan Solusinya, Puspa Swara : Jakarta

Kristiani, D \& Latifah, L (2013). Pengaruh Tehnik Relaksasi Autogenik Terhadap Skala Nyeri Pada Ibu Post Operasi Sectio Caesarea (SC) di RSUD Banyumas, Skripsi, Universitas Soedirman.

Mahdiyah, (2013). Hubugan Mobilisasi Dini Dengan Penurunan Tingggi Fundus Uteri Pada Ibu Post Partum Di BLUD RS H. MOCH Ansarti Salaeh banjarmasin. ISSN : $2086-3454$ VOL 11. NO 11 EDISI 07 JULI 2013 HAL
$(14-23)$

Manuaba I.B.G. (2010). Kapita Selekta Penatalaksanaan Rutin Obsetri Ginekologi dan KB. Jakarta : EGC

Potter dan Perry. (2005). Fundamental Keperawatan : Konsep Proses dan Praktek, Jakarta : EGC

Sumarah, 2013, Pengaruh Mobilisasi Dini Terhadap Penyembuhan Luka Post Sectio Caesarea. Jurnal Involusi Kebidanan, Vol. 3, No. 5, Januari 2013, 58-69.

Rampengan, Stania FY dkk (2013). Pengaruh Teknik Relaksasi dan teknik distraksi terhadap perubahan intensitas nyeri pada pasien post operasi di ruang Irina $A$ atas RS.DR.R D Kandou Manado (Diakses 12 Mei 2017)

Susan J.G, (2004). Dasar-dasar Terapi dan Latihan Fisik. Jakarta : Hypocrates

Soetjiningsih. 2008. Pengantar Asuhan Keperawatan Maternitas. Salemba Medika: Jakarta. 2008. Pengantar Asuhan Keperawatan Maternitas. Salemba Medika: Jakarta.

Sukirno.2008. Memahami Kesehatan Reproduksi Ibu. Jakarta: EGC

Supariasa. 2001. ASI dan Nutrisi Balita. Pustaka Abadi: Jakarta. 